\title{
Modern principles used in conformity assessment of machinery from forestry sector
}

\author{
Anca Elena Antonov ${ }^{1, *}$, Georgeta Buica ${ }^{1}$, and Constantin Beiu ${ }^{1}$ \\ ${ }^{1}$ INCDPM „Alexandru Darabont”, Certification Body, 35A Blvd, Bucharest, Romania \\ ${ }^{2}$ INCDPM „Alexandru Darabont”, Electrical and Mechanical Risks Laboratory, 35A Blvd, Bucharest, \\ Romania
}

\begin{abstract}
The paper is aiming to implement the general principles of risk prevention at employer's level, with respect to occupational risks evaluation, the elimination of risk and accident factors, and information of workers which are using the machinery in the forestry sector. For the use of machinery in the forestry sector in terms of economic performance and a level of maximum safety, it is necessary to ensure the user guides set by the manufacturer in terms of commissioning, use and to provide appropriate safe working operations and interventions and to guarantee the technical and environmental requirements, including appropriate measures and means of protection against accidents and occupational disease. The impact of occupational risks for machinery used in this sector can be reduced through the application of modern principles in conformity assessment and certification and, where appropriate, through technical diagnostics and inspection, taking into account the provisions of the new Machinery Directive 2006/42 / EC which is imposing the obligation of manufacturer to implement conformity assessment procedures in accordance with the methods of assessment and verification of safety at the certification bodies, notified at the European Commission. The paper aims to develop modern technical tools for conformity assessment and verification of this category of machines used in the forestry sector that would provide prerequisite for increasing competitiveness of employers in the market economy. Applying these tools of modern technology for manufacturers and users of this category of machinery provides the necessary conditions for placing on the market of safe products with a appropriate safety level, in the intended using conditions, in order to guarantee the essential requirements for safety and health, technical and environmental conditions, including measures and means of protection. The result of this research is to develop technical tools needed to assess compliance on effective occupational risk management for professional machinery used in the forestry sector.
\end{abstract}

\section{Introduction}

A priority objective in the Romania nowadays is the implementation of national legislation harmonized with EU legislation, as an important condition for economic integration, taking into account the provisions of Article 70 of the Law on Ratification of the European Association Agreement, which provides: "employee's safety, health and life of humans are priority areas for harmonization." In this respect, by harmonizing Romanian legislation,

\footnotetext{
${ }^{*}$ Corresponding author: aantonov@protectiamuncii.ro
} 
especially for safety and health at work, with Community law aimed, on the one hand creating working conditions at European level by Romanian regulations complying with the provisions of Directives deriving from art. 118A of the Treaty of Rome (article $137 *$ of the Treaty of Amsterdam, as amended by the article153 from the Treaty on functioning of the European Union) and on the other hand to ensure a maximum level of safety for workers by using work equipment (WE) and appropriate personal protective equipment (PPE) whose safety/protection quality to be ensured from the conception and certified by regulated procedures.

In case of work equipment, the concept of quality should be based primarily on terms of meeting the basic, function in use or safety function, relative to the user and goods /people/ animals from working environment. [1]

\section{Statistics of accidents at work in the wood processing industry, manufacture of wood}

The information presented are the results of the processing of statistical data on accidents at work and occupational diseases recorded in the wood processing industry, wood and cork products of, excepting furniture, in Romania. These data are based on activity reports for 2011- 2015 of Labour Inspection and data provided by the NSI for 2008-2015, wood processing industry is a sector whose activity has an important share, both economically and workforce involved, widely recognized as high risk, similar to constructions sector. [1, $3-4]$.

\subsection{Statistics of accidents at work in wood processing industry}

The analysis of statistics on accidents at work and occupational diseases recorded in the wood processing industry had as a starting point the share of the workforce and workers who worked in 2008-2015. The data recorded shows a decrease in employment from 2009 to 2011 and a small increase in 2014 and 2015.

Figure 1 shows the evolution of employment in the wood processing industry in 20082015, according to the NSI in section C-Manufacturing, Code 16 Wood, wood and cork products of, excepting furniture.

Analysing the statistical data, it has found that wood processing industry remains on top as the number of injured produced at work.

The statistics on accidents at work produced at national level, shows that there is a decrease in 2010-2011, followed by an increase of the number of work accidents produced in activities in this sector, in 2014 and 2015.

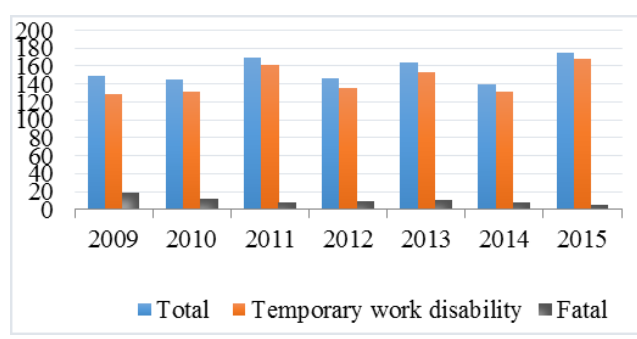

Fig.1 Evolution of workforce in wood processing sector in 2008-2015

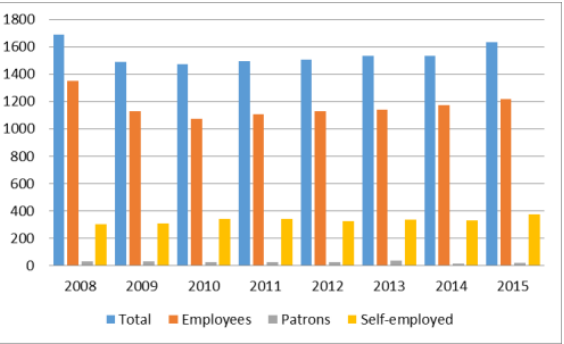

Fig.2 Statistics on accidents at work in the wood processing sector in 2008-2015 
There is a very small reduction in the number of workers involved in accidents at work in recent years and also a reduction of the number of collective accidents at work in wood processing industry, mainly due to fluctuating workload in this sector.

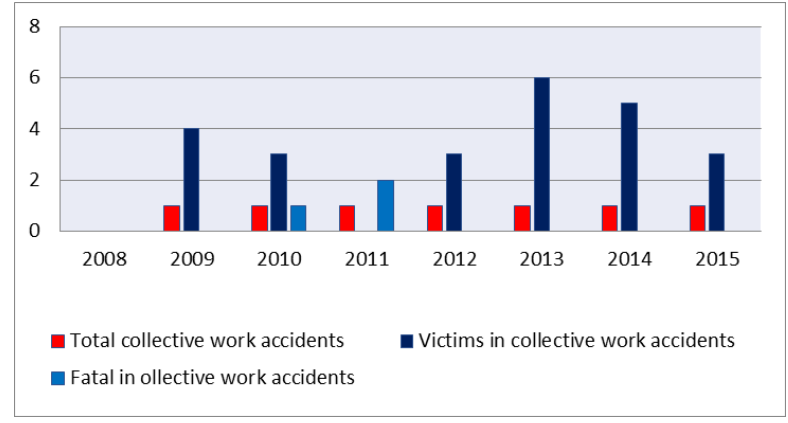

Fig.3 Statistics on collective accident at work in wood processing sector in 2008-2015

\subsection{Statistics on occupational diseases recorded in wood processing industry}

Statistics show that in the wood processing industry, manufacture of wood, the most common disorders are musculoskeletal system diseases.

\section{Principles relating to the conformity assessment of machinery used in the forestry sector}

In order to carry out conformity assessment and product certification, it applies different conformity assessment modules, according to New Approach concept, or variants of these modules. European legislation on the quality of work equipment used by employees during work is based on art. 100A of the Treaty of Rome, as amended by art. $94 \div 97$ of the Amsterdam Treaty, as amended by Article $113 \div 117$ respectively of the Treaty on functioning of the European Union (Treaty of Lisbon).

European directives arising from Article 100A contains a number of common provisions, regardless of the type of equipment to which it applies and its specific provisions, particularly in the form of essential safety requirements, including technical provisions (characteristics, parameters admissible, test methods) [1-2].

For machinery, main provisions are contained in the European Directive 2006/42/EC, which came into force from 29.12.2009. The Directive 2006/42/EC have set new safety requirements for machinery, the application of some modules for conformity assessment and ensuring total quality of manufacturing, complementary to the provisions of Directive 98/37/EC. Directive 2006/42/EC have set new safety requirements for machinery, the application of modules conformity assessment and ensuring full quality assurance of manufacturing to the provisions of Directive 98/37 / EC. According to the regulation issued by the Machinery European Directive 2006/42/EC does not apply to the lifting of persons by machinery that are not built for this purpose. This Directive allows, however, for Member States to take all measures at national level, according to the European Treaties, for machinery, in application of the Directive 89/655/EEC which refers to the harmonization in Member States of the minimum safety and health requirements for the use of work equipment by workers at work. Regarding the risks related to the use of machinery covered by Directive 2006/42/EC, it has been established procedures for assessing the 
conformity with the essential health and safety requirements, these procedures are designed according to the importance of the inherent risk that can arise from these machineries.

Consequently, each category of machinery should be harmonized for an appropriate procedure to comply with Decision 93/465 / EEC of the Council from 22 July 1993, concerning the modules for the various phases of conformity assessment and rules on the application and use of CE marking, modules which are intended to be used in the technical harmonization directives and which contains provisions relating to technical verification of these machines.

Directive 2006/42/EC introduces a number of conformity assessment procedures for machinery, according to article 12 :

- for machines that are not listed in Annex IV of the Directive, the manufacturer or his representative applies the conformity assessment procedure with internal control of production of machinery, according to Annex VIII of the Directive;

- for machines form Annex IV of the Directive and which are manufactured according to harmonized standards provided in article 7, par. (2), and for all standards which provide all the applicable essential health and safety requirements, the manufacturer or his representative applies one of the following procedures:

a) Conformity assessment procedure with internal checks on the manufacture of machinery, according to Annex VIII of the Directive;

b) The EC type-examination procedure provided by Annex IX and internal checks on the manufacture of machinery according to Annex VIII, section 3 of the Directive;

c) Full quality assurance according to Annex X;

- for machines in Annex IV of the Directive and not manufactured according to harmonized standards provided in article 7, par. (2), or only partially, or if the harmonized standards do not provide all the applicable essential health and safety requirements or no harmonized standards exist for the machine in question, the manufacturer or his representative shall apply one of the following procedures:

a) The EC type-examination procedure provided by Annex IX and internal checks on the manufacture of machinery according to Annex VIII, section 3 of the Directive;

b) In accordance with Annex. VIII, section 3 of the Directive;

c) Full quality assurance procedure according to Annex X;

- for complete parts of the machinery, the manufacturer of such party or its representative, before placing on the market must comply with Article 13 of the Directive and to adopt the following:

a) Specific technical documentation, according to Annex VII, Part B;

b) Instructions for assembly, according to Annex VI;

c) Declaration of incorporation, according to Annex II, Part 1, Section B.

Romanian legal provisions relating to conformity assessment of products, which should cover the machinery, establish the evaluation and certification activities to be carried out by competent technical bodies notified by national authorities, for each technical regulation. Guidelines for safety and health at work of legal and technical regulations to develop the course module are:

- Law no. 319/2006 on safety and health at work;

- Norms for implementing Law No 319/2006 on safety and health, approved by GD no. 1425 / 2006, amended (HG nr.955 / 2010);

- GD no.1029 / 2008 on the conditions of putting on market of machinery;

- GD no.457 / 2003 reissued, on concerning the safety of users of low voltage electrical equipment;

- GD no.1146 / 2006 on the minimum safety and health requirements for use of work equipment by workers at work, Romanian standards of product safety, etc. 
Law no. 319 / 2006 on occupational safety and health provisions of the Directive Council no.89 / 391 / EEC on the introduction of measures to encourage improvements in the safety and health of workers at work, legislation which establishes that for WE to take, from research stage, design and execution, as well as the development of manufacturing technologies, solutions to comply with legal provisions on health and safety at work, by whose application to removed or diminished the risks of injury and occupational disease for workers. In order to achieve WE without risk to health and safety, it should be ensured in the design and manufacturing, health and safety requirements laid down by technical directives or requirements of national technical regulations. WE not covered by technical regulations provided by EO no. 20 / 2010, must ensure the safety requirements of standards, technical and health and safety at work regulations, etc. In order to ensure the use of safe machinery, the designer and manufacturer of such an work equipment (WE) must prove compliance with GD nr.1029 / 2008, which is the legal document that transpose the 2006/42/EC Directive. For major electrical risk (machinery and appliances under Directive machines, except those provided for in Directive LVD 2015/35/EU which replaces Directive 2006/95 / EC) the provisions of Directive 2006/42 / EC are applied and related to emission and immunity to electromagnetic field the provisions of Directive 2014/30 / EU on electromagnetic compatibility are applied. For major electrical risk (with the exception of machinery and appliances under Directive machinery) the provisions of Directive 2006/95 / EC relating to electrical equipment designed for use within certain voltage limits are applied. WE intended for use in potentially explosive atmospheres the provisions of Directive 2014/34/EU concerning equipment and protective systems intended for use in potentially explosive atmospheres, replacing the previous Directive 94/9/EC.

In order to ensure essential health and safety requirements applicable to machines from the earliest stages of design, production and marketing, must be met the GD nr.1029 / 2008 from 29.12.2009.

Work equipment may be new, used, or from occasion, in this category are the work equipment and protective means which have already been used in an EU country and it is, again, placed on the EU market. This new placement on the market means that the occasion machinery passed the first placement on the market state and initial operation in the European Union. Reconditioned machinery that begin with the prefix indicates repeated action or return to the previous state (retro) being assigned to the existing machines that have undergone technical interventions that aimed at changing their state, performance, safety, etc. This work means changing the machine in a greater or smaller way. A "Rebuilt" or "renewed" Machine is a new machinery, built, partially or entirely, from parts from an old machinery. European technical rules that can be applied to a used or renewed machines are:

- "New Approach" Directives were designed exclusively for new products or for products considered as new.

- From technical point of view, implementation of the directives to occasion machinery is generally unrealistic.

- Although there is no legal obstacle to regulating occasion machinery through a European Directive, based on Article 100A of the Treaty of Rome, it is difficult to see how technical harmonization at different generation of machines is applied.

Health and safety requirements applicable to new, used or occasion work equipment used by employers during work activities, are provided in GD no.1146 / 2006 on safety and health at work using WE and application of these requirements must achieve the compliance with WE in use.

In this regard, for WE in use, it must be carried out an initial inspection, as their safety depends on the installation conditions, conditions after installation and before being put into service or inspection after assembly at headquarters or in a new location and / or periodic 
and special inspections and, where appropriate, testing of WE exposed to conditions that can cause damage that can result in dangerous situations [5].

Conformity assessment of woodworking machinery industry must be associated with a systematic risk assessment of workplaces in the forestry sector. There are some research that promote different methods of risk assessment at workplaces, and studies aimed at "Developing a rational systematization of 31 occupational risk assessment methods. It gives it clear selection criteria for adequate most practical application of tools. The results obtained will support the Decision - making process within the health and safety management process in industrial work environments"[6], which determines the need to apply a specific procedure of risk assessment at workplace, chosen in accordance with WE subject to compliance procedure.

Conformity assessment of woodworking machinery industry, certification and / or diagnosing of technical evaluation is performed under the compliance with applicable essential health and safety requirements and the presumption of conformity with the applicable standards to this category of machines for woodworking - Band sawing machines. The case study was made for woodworking machines which are summarized in Annex 4 of GD nr.1029 / 2004, item 1 (Annex 4 of Directive 2006/42 / EC). This study covers the identification of risk situations and hazardous events that may generate risks for workers in woodworking machines for Band sawing machines (table band saws and band re-saws) $[1,7]$.

It was identified safety checks applicable to a machinery that is subject to the "EC-type examination" ((Article 12, par.3, letter b) and point 3 / Annex 8 of Directive 2006/42 / EC and Article 13, par (3), b) Annex 9 and item 3 / Annex 8 of GD nr.1029 / 2008, in preparation for the initiation / certification procedure of machine made and marketed by a manufacturer from Alba county. The main relevant European standards for the design and manufacture of band saws and log saws to apply conformity assessment process are: EN ISO 12100: 2010 / EN ISO 12100: 2011 [8], SR EN 1807-1: 2013 / SR EN 1807-1: 2013 [9] SR EN 1807-2: 2013 / SR EN 1807-2: 2013 [10], plus the conformity assessment process and type B safety relevant standards.

Also, during the investigation, it has established the list of essential requirements and characteristics applicable to conformity assessment of woodworking machines - saws and a list of safety checks on electrical risk to be carried out in a process of conformity assessment and certification, list which is established in terms of the essential safety requirements stipulated in Directive 2006/42 / EEC (GD 1092 / 2008), GD 1146 / 2006, SR EN 1807-1: 2013 SR EN 60204-1: 2007 / AC : 2013 [6].

Table 1. Safety checks on electrical risk (excerpt)

\begin{tabular}{|c|c|c|c|c|c|c|c|}
\hline \multirow[b]{2}{*}{$\begin{array}{l}\text { Nr. } \\
\text { crt. }\end{array}$} & \multirow[b]{2}{*}{ Name checking } & \multicolumn{4}{|c|}{ Technical condition } & \multicolumn{2}{|c|}{ Check method } \\
\hline & & $\begin{array}{l}\text { GD 1029/ } \\
2008 \\
(\text { Annex 1) }\end{array}$ & $\begin{array}{c}\text { GD } \\
1146 / 2006 \\
\text { (Annex 1) }\end{array}$ & $\begin{array}{l}\text { SR EN } \\
1807-2: \\
2013\end{array}$ & $\begin{array}{c}\text { SR EN } \\
60204-1: \\
2007 / \\
\text { AC:2013 }\end{array}$ & $\begin{array}{l}\text { SR EN } \\
1807-2: \\
2013\end{array}$ & $\begin{array}{c}\text { SR EN } \\
60204-1: \\
2007 / \\
\text { AC:2013 }\end{array}$ \\
\hline 1 & $\begin{array}{l}\text { Checking the electrical } \\
\text { equipment of machines }\end{array}$ & 1.2 . & $2.1,2.2$ & 5.2 & 4.3 & 5.2 & 18.6 \\
\hline 2 & $\begin{array}{l}\text { Checking the control } \\
\text { circuits and control } \\
\text { functions }\end{array}$ & 1.2 & $\begin{array}{l}2.2,2.3 \\
2.4\end{array}$ & 5.2 & $\begin{array}{l}9.2 \\
10\end{array}$ & 5.2 & 18.6 \\
\hline 3 & $\begin{array}{l}\text { Checking the devices } \\
\text { for safe disconnecting } \\
\text { and switching off }\end{array}$ & 1.2 .4 & $\begin{array}{l}2.1 \\
2.4\end{array}$ & 5.2 & $\begin{array}{c}9.2 \\
10.7\end{array}$ & 5.2 & 18.6 \\
\hline 4 & Checking the control & 1.2 .6 & 2.3 & $5.2,5.4$ & 9.4 & $5.2,5.4$ & 18.6 \\
\hline
\end{tabular}




\begin{tabular}{|c|c|c|c|c|c|c|c|}
\hline \multirow[b]{2}{*}{$\begin{array}{l}\text { Nr. } \\
\text { crt. }\end{array}$} & \multirow[b]{2}{*}{ Name checking } & \multicolumn{4}{|c|}{ Technical condition } & \multicolumn{2}{|c|}{ Check method } \\
\hline & & $\begin{array}{l}\text { GD 1029/ } \\
2008 \\
\text { (Annex 1) }\end{array}$ & $\begin{array}{c}\text { GD } \\
1146 / 2006 \\
\text { (Annex 1) }\end{array}$ & $\begin{array}{l}\text { SR EN } \\
1807-2: \\
2013\end{array}$ & $\begin{array}{c}\text { SR EN } \\
60204-1: \\
2007 / \\
\text { AC:2013 }\end{array}$ & $\begin{array}{l}\text { SR EN } \\
1807-2: \\
2013\end{array}$ & $\begin{array}{l}\text { SR EN } \\
60204-1: \\
2007 / \\
\text { AC:2013 }\end{array}$ \\
\hline & $\begin{array}{l}\text { system in case of failure } \\
\text { of power supply and } \\
\text { control system failure }\end{array}$ & & & & & & \\
\hline 5 & Dielectric test & 1.5 .1 & $2.19,3.3$ & 5.4 & 6 & 5.4 & 18.4 \\
\hline 6 & \begin{tabular}{|l} 
Checking \\
correspondence $\quad$ with \\
wiring diagrams
\end{tabular} & 1.7 & - & $5.4,6.3$ & 17.6 & $5.4,6.3$ & 18.1 \\
\hline 7 & $\begin{array}{l}\text { Verifying the existence, } \\
\text { content and } \\
\text { sustainability } \\
\text { markings }\end{array}$ & 1.7 & 2.1 & 6.2 & 16 & 6.2 & 16 \\
\hline
\end{tabular}

In the research study carried out, were applied principles of conformity assessment of machinery used in the forestry sector, principles implemented by the competent certification / notified body (INCDPM) through a set of technical tools of modern conformity assessment and certification of these machines using $3 \mathrm{EV}$ methods: applicable evaluation, testing, certification, and WE in use in terms of principle: inspection-testingassessment-compliance through a process of compliance.

The research study shows the need to approach all mandatory steps for conformity assessment and certification and / or compliance of the WE, regardless of the sector they are intended to be used.

\section{Conclusion}

The work aimed to develop modern technical tools for conformity assessment and verification of this category of machines used in the forestry sector, to ensure employers prerequisite for increasing competitiveness in the market economy.

Applying these tools of modern technology for manufacturers and users of this category of machines, provides the necessary conditions for puting on to market of safe products with a level of safety appropriate to the conditions of intended use in order to guarantee the essential requirements for safety and health, technical and environment, including measures and means of protection.

The research results consist of the development of technical tools needed to assess compliance on effective management of professional risks for machines used in the forestry sector.

\section{References}

1. INCDPM, Tools for prevention of occupational risks for SMEs to ensure design and manufacturing requirements for work equipment used in the wood and metal processing industries - prerequisite for improving SME productivity through safe and healthy workplaces, research study (2015)

2. INCDPM, Safety and health at work in the Construction sector. Training coordinators for safety and health at work, course module, (119-145, 2017)

3. A.E. Antonov, G.Buica, D.C.Darabont, C.Beiu, 7th International Multidisciplinary Scientific Symposium, Conference Proceedings, 1, 235-240, (published "Calitatea - acces la succes" Journal, 18 (S1) ( 2017) 
4. INCDPM- Guidelines for safety and health at work in the construction sector, developed in the project POSDRU/81/3.2/S55075 funded by European Social Fund - Sectorial Operational Programme Human Resources Development 2007 - 2013, 15-18 (2012)

5 European Commission (2010), Guide for application of the Machinery Directive 2006/42/EC, 126-129 (in Romanian)

6. Moraru, R. I., Băbuț, G. B., Cioca, L. I.- Rationale and criteria development for risk assessment tool selection in work environments, Environmental Engineering and Management Journal, 13 (6), 1371-1376 ( 2014)

7. INCDPM - Maintaining the competences ICSPM-CS certification body in accordance with procedures ICSPM-CS and CB accreditation criteria - case studies (2017)

8. EN ISO 12100:2010 Safety of machinery - General principles for design - Risk assessment and risk reduction (ISO 12100:2010)

9. EN 1807-1:2013 Safety of woodworking machines. Band sawing machines. Table band saws and band re-saws

10. EN 1807-2:2013 Safety of woodworking machines. Band sawing machines. Log sawing machines 